Research Article

\title{
Growth, Nitrogen Uptake of Maize (Zea mays L.) and Soil Chemical Properties, and Responses to Compost and Nitrogen Rates and Their Mixture on Different Textured Soils: Pot Experiment
}

\author{
Ashenafi Nigussie $\mathbb{D}$, ${ }^{1}$ Wassie Haile $\mathbb{D}^{\mathbb{D}},{ }^{2}$ Getachew Agegnehu $\mathbb{D}^{3},{ }^{3}$ and Alemayehu Kiflu $\mathbb{i D}^{2}$ \\ ${ }^{1}$ Department of Natural Resource Management, Wondo Genet Agricultural Research Center, Shashemene, Ethiopia \\ ${ }^{2}$ School of Plant and Horticultural Sciences, Hawassa University College of Agriculture, Hawassa, Ethiopia \\ ${ }^{3}$ Department of Natural Resource Management, Holeta Agricultural Research Center, Holeta, Ethiopia
}

Correspondence should be addressed to Ashenafi Nigussie; nigussie.ashenafi@yahoo.com

Received 10 March 2021; Accepted 27 July 2021; Published 9 August 2021

Academic Editor: Claudio Cocozza

Copyright ( $) 2021$ Ashenafi Nigussie et al. This is an open access article distributed under the Creative Commons Attribution License, which permits unrestricted use, distribution, and reproduction in any medium, provided the original work is properly cited.

\begin{abstract}
Integrated nutrient management, which primarily involves the combined application of organic and inorganic nutrient sources, is one of the simplest approaches to handle declining soil fertility challenges and increase crop productivity and production. Keeping in view this fact, a pot experiment was conducted to evaluate the effects of compost and inorganic nitrogen fertilizer and their mixture on soil properties, growth, and nitrogen uptake of maize on loam and clay textured soils at the Awada Agricultural Research Subcenter. Treatments comprised factorial combinations of five compost rates $\left(0,5,10,15\right.$, and 20 t.ha $\left.{ }^{-1}\right)$ and four rates of inorganic nitrogen fertilizer $\left(0,46,92\right.$, and $\left.138 \mathrm{~kg} \cdot \mathrm{N} \cdot \mathrm{ha}{ }^{-1}\right)$ laid out as a completely randomized design with three replications. Results showed that both the main and interaction effects of compost and mineral $\mathrm{N}$ fertilizer rates significantly affected the selected soil chemical properties and yield, and nitrogen concentration of maize. There were significant associations between plant parameters and soil nitrogen contents. The addition of $92 \mathrm{~kg} \cdot \mathrm{ha}^{-1} \cdot \mathrm{N}+10 \mathrm{t} \cdot \mathrm{ha}^{-1}$ compost and $46 \mathrm{~kg} \cdot \mathrm{ha}^{-1} \cdot \mathrm{N}+10 \mathrm{t} \cdot \mathrm{ha}{ }^{-1}$ compost was the best treatments for loam and clay textured soils of the study areas, which improved shoot dry matter by 179.5 and $284.5 \%$, compared to the unfertilized pot, respectively. From the results of this experiment, we concluded that the integrated application of compost and mineral nitrogen fertilizer enhanced soil chemical properties and thus improved nitrogen uptake and sustainable production of maize in the study areas.
\end{abstract}

\section{Introduction}

Soil is the most prominent natural resource that provides important ecological services for human beings, such as regulation of nutrient and water cycling, carbon sequestration, and preservation of biodiversity [1]. During the current past, the utilization of natural resources is increased due to global population stress, particularly in arid and semiarid regions, and thus becomes threatened for the sustainable farming system [2]. Widespread land degradation and low soil fertility are the major biophysical root causes of declining per-capita food production in Sub-
Saharan Africa [3]. In the tropics, soil fertility management has become a major concern on smallholder farmers to sustain their agricultural production [4]. Thus, adopting context-specific soil management practices is crucial for sustainable agricultural productivities and environmental quality.

In Ethiopia, over $80 \%$ of the population depends on land for their livelihoods and nourishment [5], but $31 \%$ of their land resources are currently degraded [6]. In resourcelimited farmers, soil fertility degradation has been the bottleneck to sustainable agricultural productivity [7]. According to Gelaw et al. [8], loss of soil organic matter due 
to topsoil erosion along with poor physicochemical properties is the prominent causes for the deterioration of soil fertility and productivity. Balanced and careful use of external inputs together with eco-friendly and environmentally sound soil management practices is essential issues for sustainable agriculture production [9]. Lal [10] indicated that the implementation of improved soil management practices could affect the sustainable use of soil resources through their impacts on soil quality, stability, and resilience to climate change. Therefore, restoring soil fertility through fertilizer application is essential to improve and maintain crop yields over a period.

Nitrogen (N) is a universally deficient element in almost all the agricultural soils and cropping systems of the world [11]. Among cereals, maize required an adequate amount of nutrients, particularly $\mathrm{N}$ for optimum growth and yield [12]. Limited nitrogen could exert a substantial effect on maize crop yield and yield components as the plant would remain small and rapidly turn yellow [13]. Previous studies have indicated that maize grain yield significantly increased by about 43-68\%, due to N [14]. Therefore, nitrogen management in the maize cultivation system is one of the major concerns and the most yield-limiting element $[15,16]$.

In modern agriculture, intensive cultivation through extreme use of chemical fertilizers is considered as a means to boost crop yields and thus demonstrated as a convenient soil management option than the use of organic inputs. However, extreme use of chemical fertilizers has brought several soil fertility problems, including soil acidity [17], soil structure and quality deterioration, and low nitrogen use efficiency [18] and crop yields over time [19]. The destructive effects of chemical fertilizers, together with unaffordable price expenses, have led to use of organic inputs as a source of nutrients [20]. Organic inputs such as farm yard manure (FYM), compost, or manure can contribute to the organic components of the soil, thereby improving friability, waterholding capacity, and cation exchange capacity of the soil. Soils amending with organic fertilizers have positive effects on the soil productivity and quality $[20,21]$. Fereidooni et al. [22] observed that the addition of organic inputs improved the soil physical properties, which leads to a better environment for root development, water retention, nutrient exchange, and soil health. Hence, the usage of locally available organic resources in agricultural soil is crucial to improve and sustain crop productivity.

However, the use of organic inputs individually as a substitute for inorganic fertilizer is not sufficient to increase crop yields and satisfy the food needs of humankind since organic fertilizers are of a slow-release nature and will not fully deliver the required quantities of nutrients via plants [23]. Hence, the integrated application of organic and inorganic fertilizer inputs is the most convenient nutrient management method to increase nutrient synchrony and decreases losses of nutrients through leaching [24]. The combined application of organic and inorganic fertilizer inputs is important to improve soil fertility, crop productivity, nutrient use efficiency, and protect soil health [20]. Earlier studies also proved the positive effect of the integrated application of organic and inorganic $\mathrm{N}$ sources, in supporting higher growth and yield of maize [25, 26]. Several fields and greenhouse studies have shown that sustainable crop yields are possible with combined application of organic and inorganic inputs [27, 28, 29]. Furthermore, the cost of inorganic fertilizers has been decreased by $25 \%$ [30] and $50 \%$ [31] when integrated organic and inorganic inputs applied. Therefore, the combined use of organic and synthetic fertilizers has considerable importance as to take corrective measures in soil fertility improvement, sustainable crop productivity, and economic viability.

Although studies at the separate impacts of organic and synthetic fertilizer inputs on crop growth, yield, and soil characteristics were undertaken, facts at the combined consequences of compost and inorganic nitrogen fertilizer on soil characteristics, growth, and yield and nitrogen uptake of the study areas are generally inadequate. In addition to these, maize is an intensively cultivated cereal crop in Hawassa Zuria and Meskan districts; however, site-specific soil and crop response to integrated organic and inorganic fertilizer input studies is not yet properly executed. Therefore, a pot study was conducted to evaluate the effects of compost and inorganic nitrogen fertilizer and their mixture on maize growth, yield and nitrogen uptake, and soil properties and to determine optimum integrated organic and inorganic $\mathrm{N}$ rates for each soil type of the area. We hypothesized that the application of integrated organic and inorganic nitrogen fertilizer will improve soil properties, growth, yield, and yield components.

\section{Materials and Methods}

2.1. Characterization of the Experimental Soil and Compost. Bulk surface soils were collected from the Anchamo maize farm of Hawassa Zuria District (70 1'0.83" N, $\left.38022^{\prime} 26^{\prime \prime} \mathrm{E}\right)$ and Nasri maize farm of Meskan District $\left(08^{\circ} 05^{\prime} 33^{\prime \prime} \mathrm{N}\right.$ Latitude and $38^{\circ} 26^{\prime} 75^{\prime \prime}$ E Longitude) at depth of $0-20 \mathrm{~cm}$ in Southern Ethiopia. The experimental soils are loam and clay textured for Hawassa Zuria and Meskan, respectively. Earlier to planting, three subsamples were taken from each soil type for soil physicochemical analysis. The collected soil samples were air-dried and sieved with $2 \mathrm{~mm}$ sieve; however, a $0.5 \mathrm{~mm}$ sieve was used for the analysis of organic carbon and total nitrogen.

The compost was prepared at the Wondo Genet Agriculture Research Center Botanical Backyard using locally available composting materials such as green leaves, farmyard manure, fresh and dry cow dungs, and animal feed remains from dairy cattle, and wood ash. A homogenized mixture of composting materials was composted in pits of $2 \mathrm{~m} \times 1.5 \mathrm{~m}$ wide by $1.5 \mathrm{~m}$ deep. Those composting materials were located in alternating sheets, with a maize straw material starting the bottom layer. All recommended management practices were operated as required until the materials were ready for use. Three representative compost subsamples were taken to analyse $\mathrm{pH}, \mathrm{EC}, \mathrm{OC}, \mathrm{TN}$, Avail-P, and $\mathrm{C}: \mathrm{N}$ ratio. The collected samples were air-dried, ground, and sieved through a $2 \mathrm{~mm}$ sieve whereas a $0.5 \mathrm{~mm}$ sieve was used for OC and TN. The selected chemical properties of the compost used in this study are presented in Table 1 . 
TABLE 1: Selected physicochemical properties of the soils and compost earlier treatment application.

\begin{tabular}{|c|c|c|c|c|c|c|}
\hline \multirow{3}{*}{$\begin{array}{l}\text { Soil } \\
\text { properties }\end{array}$} & \multicolumn{6}{|c|}{ Soil } \\
\hline & \multirow[t]{2}{*}{ Units } & \multicolumn{2}{|c|}{$\begin{array}{c}\text { Hawassa } \\
\text { Zuria site } \\
\text { (loam) }\end{array}$} & \multicolumn{2}{|c|}{$\begin{array}{l}\text { Meskan } \\
\text { site (clay) }\end{array}$} & \multirow[t]{2}{*}{ Compost } \\
\hline & & Mean & $\mathrm{SD}$ & Mean & SD & \\
\hline \multicolumn{7}{|c|}{ Physical properties } \\
\hline Sand & $\%$ & 41.3 & \pm 1.15 & 16 & \pm 2.00 & - \\
\hline Silt & $\%$ & 33.4 & \pm 1.15 & 36 & \pm 3.46 & - \\
\hline Clay & $\%$ & 25.3 & \pm 1.15 & 48 & \pm 2.00 & - \\
\hline Textural class & - & Loam & & Clay & & - \\
\hline \multicolumn{7}{|c|}{ Chemical properties } \\
\hline $\mathrm{pH}$ & - & 5.91 & \pm 0.08 & 6.8 & \pm 0.44 & 6.79 \\
\hline EC & $\mathrm{ds} / \mathrm{m}$ & 0.03 & \pm 0.00 & 0.06 & \pm 0.01 & 0.09 \\
\hline OC & $\%$ & 2.55 & \pm 0.14 & 3.98 & \pm 0.45 & 14.8 \\
\hline $\mathrm{TN}$ & $\%$ & 0.26 & \pm 0.01 & 0.35 & \pm 0.03 & 1.21 \\
\hline $\mathrm{C}: \mathrm{N}$ & - & 9.8 & \pm 0.44 & 11.45 & \pm 1.91 & 12.23 \\
\hline Avail-P & $\mathrm{mg} \cdot \mathrm{kg}^{1}$ & 4.36 & \pm 0.16 & 22.69 & \pm 3.01 & 77.1 \\
\hline CEC & $\mathrm{cmol}_{\mathrm{c}} \cdot \mathrm{kg}^{1}$ & 21.47 & \pm 1.29 & 62.00 & \pm 2.65 & - \\
\hline
\end{tabular}

Percentage of silt, sand, and clay was determined by the hydrometer method using one percent sodium hexameter phosphate as a dispersing agent, and the textural class was determined using the USDA textural triangle [32]. The $\mathrm{pH}$ $\left(\mathrm{H}_{2} \mathrm{O}\right)$ was determined in a $1: 2.5$ soil-to-water ratio using a $\mathrm{pH}$ meter while the electrical conductivity was determined in a $1: 5$ soil-to-water ratio using a conductivity meter described by Sertsu and Bekele [32]. Soil organic carbon (OC) was determined following the Walkley and Black wet oxidation method [33], and soil total nitrogen by the Kjeldahl method [34]. Available phosphorus (Avail-P) inside the soil was determined using the sodium bicarbonate solution extraction ( $\mathrm{pH}$ 8.5) method, and the quantity was measured using a spectrophotometer as defined by way of Olsen et al. [35], and cation exchange capacity (CEC) by saturating the soil with a neutral $1 \mathrm{M}$ $\mathrm{NH}_{4} \mathrm{OAc}$ (ammonium acetate) method at $\mathrm{pH} 7$ [34]. The selected soil physicochemical earlier to treatment amendment is presented in Table 1.

2.2. Experimental Procedure. A greenhouse experiment was conducted at the Awada Agricultural Research Subcenter in Sidama Zone, Southern Ethiopia, from October 1 to November 22/2019. The plastic pot used for this trial had a $23 \mathrm{~cm}$ upper and $19.2 \mathrm{~cm}$ lower diameter, a depth of $19.5 \mathrm{~cm}$, and a total volume of proximately $6833.5 \mathrm{~cm}^{3}$ and perforated at the bottom for drainage outlets. Two kg of airdried soil was placed in each pot after screened through a $6 \mathrm{~mm}$ sieve. The treatments comprised factorial combinations of five levels of compost $\left(0,5,10,15\right.$, and $\left.20 \mathrm{t} \cdot \mathrm{ha}^{-1}\right)$ and four rates of inorganic nitrogen fertilizer $(0,46,92$, and $138 \mathrm{~kg} \cdot \mathrm{N} \cdot \mathrm{ha}^{-1}$ ) laid out in a completely randomized design (CRD) with three replications. The organic rates (compost) were based on the respective inorganic $\mathrm{N}$ equivalence of 0 , $25,50,75$, and $100 \%$; the aim was to reach a fertilization rate equivalent in $\mathrm{N}$ to those applied to the pots that received mineral fertilization.

The soil moisture within the pots was kept close to field capacity until seed sowing, and before planting, it was left for 10 days to allow an organic amendment to mix properly with the soil. Four maize (Zea mays L.) seeds of var. Bako hybrid (BH-546) were sown per pot at a depth of $3 \mathrm{~cm}$. The entire quantity of phosphorus fertilizer (triple superphosphate) was applied uniformly to all pots except for the control at the rate of $20 \mathrm{~kg} \cdot P \cdot h \mathrm{C}^{1}$. The calculated dose of nitrogen-containing fertilizer (Urea) was applied at sowing as per treatment. Thinning of the crop was done about eight days after sowing keeping two plants per pot to maintain a uniform plant stand in all experimental units. Crop was irrigated carefully considering the field capability of each soil type with the aid of the given formula: field capacity multiplied by the amount of soil in the pot. Other crop management practices were made uniformly on all pots to keep away from the competition of weeds and keep free from insects, pests, and disease attacks. Moreover, the visual observation was used to identify any ordinary signs and symptoms.

2.3. Data Collection. After experimentation, soil samples were collected from each pot and soil type, then the collected samples were combined as per treatments, making a bulk sample, and after manual homogenization, representative composite subsamples per treatment and site were prepared for selected chemical analysis.

\subsection{Measuring Plant Growth Parameters and Nitrogen} Content. Plant height was measured at fifty-two days after sowing with the aid of a meter rod from the soil surface to the top of the plant, and their mean was used for computation. The number of leaves per plant (NLPP) was counted 52 days after sowing. Normalized Difference Vegetative Index (NDVI) value was measured using a Green Seeker ${ }^{\mathrm{TM}}$ Handheld Optical Sensor Unit (NTech Industries, Inc., USA) on weeks 4, 5, and 6 after sowing, and their means were used for computation. Stem girth was measured 52 days after sowing, using a digital caliper. The aboveground parts of the plant were harvested 52 days after sowing at the soil level, and their fresh weights were weighed using an electronic sensitive balance. Similarly, the root parts were separated carefully and cleaned using water and weighed. Air-dried shoots and roots parts of the plants were oven-dried independently at $65^{\circ} \mathrm{C}$ to constant weight and measured using an electronic sensitive balance. After oven drying, the shoot samples were milled to bypass via a $0.5 \mathrm{~mm}$ sieve, and the tissue nitrogen concentration was determined by the Kjeldahl procedure after wet digestion using $\mathrm{H}_{2} \mathrm{SO}_{4} / \mathrm{H}_{2} \mathrm{O}_{2}$. The total nitrogen concentration/uptake was calculated by multiplying the nitrogen concentration in the tissue with the total shoot dry weight $\left(\mathrm{kg} \cdot \operatorname{pot}^{1}\right)$ of maize, as presented in the following equation [36]: 
total nitrogen content $\left(\frac{\mathrm{mg}}{\mathrm{pot}}\right)=\left\{\right.$ nitrogen concentration in tissue $\left(\frac{\mathrm{mg}}{\mathrm{kg}}\right) *$ shoot dry matter yield $\left.\left(\frac{\mathrm{kg}}{\text { pot }}\right)\right\}$.

2.5. Statistical Analysis. Prior to the analysis of variance (ANOVA), the assumption of normality was checked using the Shapiro-Wilk normality test, and then the collected data were exposed to the analysis of variance following the general linear model procedure (PROC GLM) of SAS 9.3 software package [37]. The following model was used to compute the general variability of the trait:

$$
T_{i j k}=\mu+R_{i}+C_{j}+N_{k}+\mathrm{CN}_{(j k)}+e_{i j k},
$$

where $T_{i j k}$ is the total observation, $\mu$ grand mean, $R_{i}$ is the effect of the $i$ th replication, $C_{j}$ is the effect of the $j$ th compost level, $N_{k}$ is the effect of the $k$ th nitrogen rate, $\mathrm{CN}$ is the interaction, and $e_{i j k}$ are the differences due to random error. Differences among treatments were separated with the protected least significant difference (LSD) at $P \leq 0.05$ probability level. The principal component analysis (PCA) was executed using SAS PRINCOMP procedure. Pearson correlation coefficient $(r)$ was performed using SAS software 9.3 [37]. All graphs were designed using Sigma Plot 14.0 procedures.

\section{Results and Discussion}

3.1. Soil Properties Earlier Treatment Application. The initial soil physicochemical properties at Hawassa Zuria showed that sand separated dominates the experimental soil $(41.3 \%)$ followed by silt (33.4\%) and clay (25.3\%) rated as high and moderate according to Hazelton and Murphy [38] and classified as loam in texture. While in Meskan soil, clay particles $(48 \%)$ dominated the mineral fraction followed by silt (35\%) and sand (17\%) rated as high, moderate, and low, respectively, and classified as clay in texture. According to Benton [39], the soil $\mathrm{pH}$ in $\mathrm{H}_{2} \mathrm{O}$ was 5.91 at Hawassa Zuria and 6.8 at Meskan, which are moderately acidic and neutral, respectively. Organic carbon contents were 2.55 and $3.98 \%$ for Hawassa Zuria and Meskan soils, respectively, and rated as medium and high [40]. The higher carbon contents may contribute to the greater total soil nitrogen at the Meskan site as compared to Hawassa Zuria soil. The available phosphorus content of the soils was 4.36 and $22.69 \mathrm{mg} \cdot \mathrm{kg}^{-1}$ in Hawassa Zuria and Meskan, respectively, and rated as low and extremely high [41]. Generally, the soil analysis results earlier treatment application indicated that the nitrogen content of the soils was found at medium range. Hence, low-to-medium soil total nitrogen levels indicate that the experimental soils require the addition of external nitrogen-containing inputs to restore and maintain their fertility status.

3.2. Effects of Compost and Nitrogen Fertilizer Rates on Selected Soil Chemical Properties. In both soil types, after harvest, soil reaction in water $(\mathrm{pH})$, soil organic carbon, total nitrogen, and avail-P significantly responded to the treatments (Table 2, Figures 1 and 2). Soil reaction in water $(\mathrm{pH})$ was significantly improved from 5.8 to 6.4 for Hawassa Zuria soil and 6.9 to 7.3 for Meskan soil due to the treatments, with the highest being from the application of $15 \mathrm{t} \cdot \mathrm{ha}^{-1}$ compost and $92 \mathrm{~kg} \cdot \mathrm{ha}^{-1} \cdot \mathrm{N}+15 \mathrm{t} \cdot \mathrm{ha}^{-1}$ compost for Hawassa Zuria and Meskan soils, respectively, whereas the lowest value was obtained from the unfertilized (control) treatment (Table 2). In Hawassa Zuria and Meskan soils, the addition of compost at the rate of $15 \mathrm{t} \cdot \mathrm{ha}^{-1}$ improved the soil reaction $(\mathrm{pH})$ by $10.3 \%$ and $5.8 \%$ compared to the control treatment, respectively, suggesting basic cations added to the soil solution through the decomposition of compost. This shows that the application of compost had a positive effect on improving the soil reaction as compared with synthetic nitrogen fertilizer. Previous research has proven that the addition of animal manure has the capacity to preserve and raise soil reaction $(\mathrm{pH})$ [42].

Likewise, the integrated use of compost and inorganic nitrogen fertilizer had a significant effect on soil organic carbon (Figures 1 and 2). In both soil types, the maximum soil OC was achieved from the addition of $20 \mathrm{t} \cdot \mathrm{ha}^{-1}$ compost and $138 \mathrm{~kg} \cdot \mathrm{ha}^{-1}$ inorganic $\mathrm{N}$, but the minimum OC was obtained from the control treatment (Figures 1 and 2 ). The results of the current study revealed that OC significantly improved with the addition of compost. This could be due to the properties of compost, which act as the storehouse of diverse plant nutrients and increased microbial biomass carbon. Dhillon et al. [42] made a comparable remark and stated that organic inputs were influential in improving and sustaining soil OC as compared to inorganic $\mathrm{N}$ sources. Hafidi et al. [43] described that the use of manure singly or in mixture with mineral fertilizer resulted in higher soil organic carbon content than the single application of mineral fertilizers.

In both soil types, the addition of compost and nitrogen fertilizer also significantly improved the total nitrogen content ( Figures 1 and 2). The highest soil TN $0.29 \%$ and $0.44 \%$ for Hawassa Zuria and Meskan soil was recorded with the addition of the highest rate of inorganic $\mathrm{N}$ and compost integrated, suggesting additional $\mathrm{N}$ released from compost through decomposition and mineralization process. Preusch et al. [44] reported that composts affected soil $\mathrm{N}$ mineralization because of the presence of strong $\mathrm{N}$ compounds found in it. However, the lowest soil TN $(0.2 \%)$ was obtained from $20 \mathrm{t} \cdot \mathrm{ha}^{-1}$ compost, which is statistically similar with the control (Figure 1(a)). The reason for this could be the immobilization of $\mathrm{N}$ released from compost for a short time by soil microorganisms with the absence of inorganic $\mathrm{N}$ as a substrate for them, which is similar to the outcomes of an earlier study [29]. Likewise, Yan et al. [45] stated that inorganic $\mathrm{N}$ fertilizer influences most soil biological processes, which is vital in mineralization and nutrient transformation. In general, compost addition positively affects the accessibility of inherent or applied nutrients as compared with the unfertilized (control) and inorganic $\mathrm{N}$ fertilizer only. 
TABLE 2: Interaction effects of different compost and inorganic nitrogen rates on soil $\mathrm{pH}$, and available soil $\mathrm{P}$ after crop harvest.

\begin{tabular}{|c|c|c|c|c|c|c|c|c|c|c|}
\hline \multirow{3}{*}{$\mathrm{N}\left(\mathrm{kg} \cdot \mathrm{ha}^{1}\right)$} & \multicolumn{7}{|c|}{ Hawassa Zuria soil } & \multicolumn{3}{|c|}{ Meskan soil } \\
\hline & \multicolumn{10}{|c|}{ Compost rates $\left(\mathrm{t} \cdot \mathrm{ha}^{1}\right)$} \\
\hline & 0 & 5 & 10 & 15 & 20 & 0 & 5 & 10 & 15 & 20 \\
\hline 0 & $5.80^{\mathrm{e}}$ & $5.90^{\mathrm{de}}$ & $5.9^{\mathrm{de}}$ & $6.4^{\mathrm{a}}$ & $\begin{array}{c}\text { Soil pH } \\
6.2^{b}\end{array}$ & $6.9^{\mathrm{d}}$ & $6.9^{\mathrm{d}}$ & $7^{\mathrm{cd}}$ & $7.1^{\mathrm{bc}}$ & $7^{\mathrm{cd}}$ \\
\hline 46 & $5.9^{\mathrm{de}}$ & $6.00^{\mathrm{cd}}$ & $6.00^{\mathrm{cd}}$ & $6.20^{\mathrm{b}}$ & $6.00^{\mathrm{cd}}$ & $7.1^{\mathrm{bc}}$ & $7.1^{\mathrm{bc}}$ & $7.1^{\mathrm{bc}}$ & $7.2^{\mathrm{ab}}$ & $7.2^{\mathrm{ab}}$ \\
\hline 92 & $6.00^{\mathrm{cd}}$ & $6.00^{\mathrm{cd}}$ & $6.00^{\mathrm{cd}}$ & $6.10^{\mathrm{bc}}$ & $6.20^{\mathrm{b}}$ & $7.1^{\mathrm{bc}}$ & $7^{\mathrm{cd}}$ & $7.1^{\mathrm{bc}}$ & $7.3^{\mathrm{a}}$ & $7.2^{\mathrm{ab}}$ \\
\hline 138 & $6.10^{\mathrm{bc}}$ & $5.90^{\mathrm{de}}$ & $5.90^{\mathrm{de}}$ & $6.10^{\mathrm{bc}}$ & $6.10^{\mathrm{bc}}$ & $7.2^{\mathrm{ab}}$ & $7.1^{\mathrm{bc}}$ & $7.1^{\mathrm{bc}}$ & $7.2^{\mathrm{ab}}$ & $7.1^{\mathrm{bc}}$ \\
\hline LSD $(0.05)$ & & & 0.135 & & & & & 0.13 & & \\
\hline & & & & & $i l-P(m g$ & & & & & \\
\hline 0 & $3.26^{\mathrm{k}}$ & $2.72^{1}$ & $3.36^{\mathrm{j}}$ & $2.57^{\mathrm{m}}$ & $2.67^{1^{\circ}}$ & $17.36^{\mathrm{i}}$ & $17.7^{\mathrm{hi}}$ & $19.33^{\mathrm{g}}$ & $18.96^{\mathrm{gh}}$ & $18.81^{\mathrm{g}}$ \\
\hline 46 & $3.56^{\mathrm{i}}$ & $3.66^{\mathrm{h}}$ & $4.5^{\mathrm{d}}$ & $5.23^{\mathrm{a}}$ & $4.77^{\mathrm{c}}$ & $18.8^{\mathrm{gh}}$ & $20.3^{\mathrm{fg}}$ & $22.12^{\text {def }}$ & $23.66^{\mathrm{bcd}}$ & $21.48^{\mathrm{ef}}$ \\
\hline 92 & $3.76^{\mathrm{g}}$ & $4.30^{\mathrm{e}}$ & $4.85^{\mathrm{b}}$ & $4.90^{\mathrm{b}}$ & $4.70^{c}$ & $18.9^{\mathrm{gh}}$ & $21.4^{\mathrm{ef}}$ & $24.00^{\text {bcd }}$ & $24.35^{\mathrm{bc}}$ & $28.81^{\mathrm{a}}$ \\
\hline 138 & $3.51^{\mathrm{i}}$ & $4.04^{\mathrm{f}}$ & $4.04^{\mathrm{f}}$ & $4.85^{\mathrm{b}}$ & $4.73^{\mathrm{c}}$ & $18.7^{\text {gh }}$ & $22.5^{\text {cde }}$ & $21.43^{\mathrm{ef}}$ & $29.58^{\mathrm{a}}$ & $25.09^{b}$ \\
\hline LSD (0.05) & & & 0.066 & & & & & 2.06 & & \\
\hline
\end{tabular}

Within the columns, means followed through the same letters are not significantly different at $P>0.05$ (LSD).

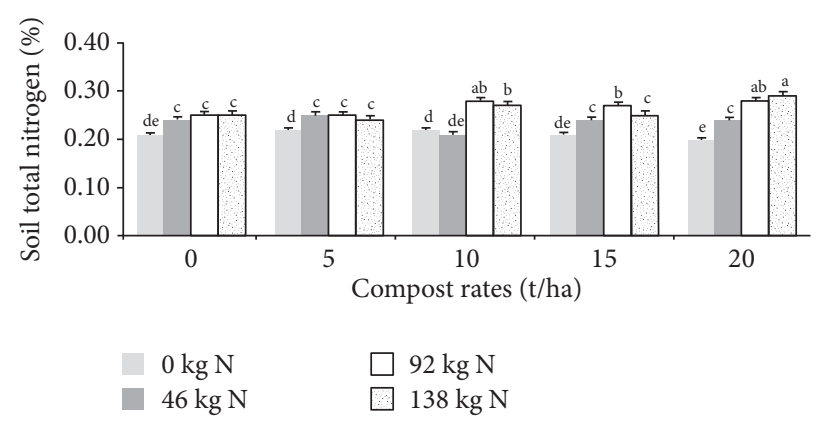

(a)

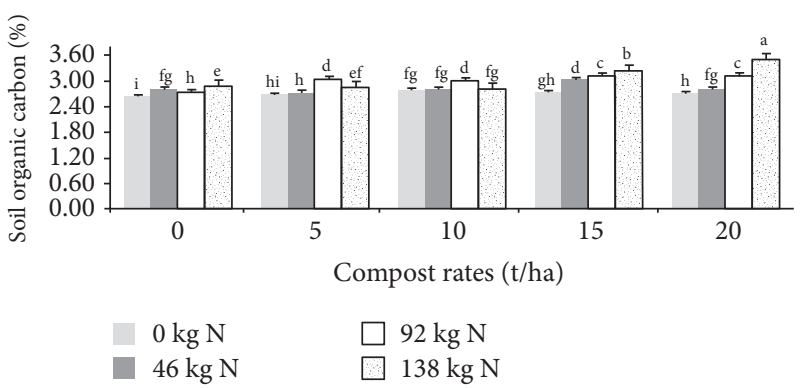

(b)

FIGURE 1: Effects of inorganic nitrogen and compost rates on soil total nitrogen (a) and organic carbon (b) after crop harvest in Hawassa Zuria soil. Unlike letters, imply significance difference between treatments at $P<0.05$ (LSD).

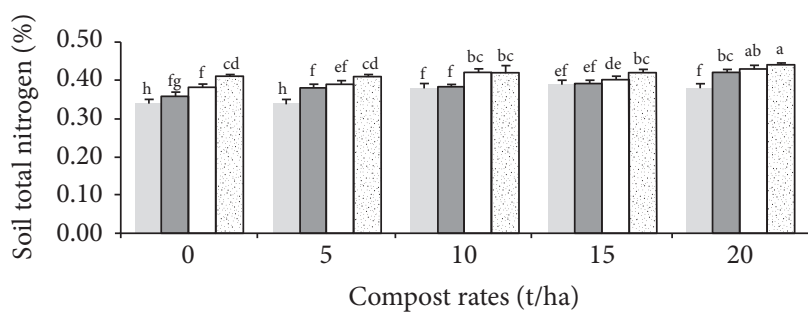

(a)

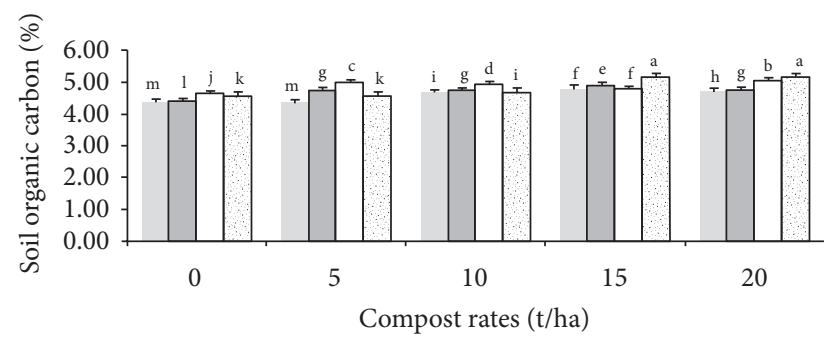

(b)

FIGURE 2: Effects of inorganic nitrogen and compost rates on soil total nitrogen (a) and organic carbon (b) after crop harvest in Meskan soil. Different letters imply significance difference between treatments at $P<0.05$ (LSD).

In both soil types, the separate and combined addition of compost and inorganic nitrogen showed a significant influence on the available phosphorus content of the soil. In Hawassa Zuria soil, the available phosphorus was low and ranged from 2.57 to $5.23 \mathrm{mg} \cdot \mathrm{kg}^{-1}$ (Table 2). This could be due to the high $\mathrm{P}$ fixation power of the soil properties, which is Andisols, whereas in Meskan soil, available phosphorus was very high and fluctuated from 17.36 to $29.59 \mathrm{mg} \cdot \mathrm{kg}^{1}$, where the soil $\mathrm{pH}$ was neutral and the neutral $\mathrm{pH}$ has low $\mathrm{P}$ fixation power. In the current study, with the addition of inorganic $\mathrm{N}$ fertilizer along with 10,15 , and $20 \mathrm{t} \cdot \mathrm{ha}^{-1}$ compost rates, soil avail-P significantly improved, suggesting additional $\mathrm{P}$ supplemented with compost through decomposition and mineralization process. This argument is consistent with the findings of Sarwar et al. [46] who described that combined application of compost and NPK mineral fertilizers significantly improved soil avail-P. In Hawassa Zuria soil with the absence of inorganic nitrogen, 
available soil $\mathrm{P}$ concentration had shown a decreased trend even if all experimental units used an equal amount of $P$. The reason for this could be immobilization of $\mathrm{P}$ by soil microorganisms with the absence of inorganic $\mathrm{N}$ as a substrate for them; moreover, phosphorus immobilization is great in soils having amorphous Fe and Al hydroxides and allophane, which is the typical property of Andisols.

\subsection{Effects of Compost and Inorganic Nitrogen Rates on Maize} Growth. The result of this analysis shows that the main and interaction effects of inorganic $\mathrm{N}$ fertilizer and compost significantly affected maize plant height (Table 3). In Hawassa Zuria soil, the tallest plant height $(76.8 \mathrm{~cm})$ of maize was obtained from the combined application of $138 \mathrm{~kg} \cdot \mathrm{ha}^{-1} \cdot \mathrm{N}$ and $10 \mathrm{t} \cdot \mathrm{ha}^{-1}$ compost, which is statistically comparable with $138 \mathrm{~kg} \cdot \mathrm{ha}^{-1} \cdot \mathrm{N}+10 \mathrm{t} \cdot$ compost $^{-h^{-1}}$ and $92 \mathrm{~kg} \cdot \mathrm{ha}^{-1} \cdot \mathrm{N}+15 \mathrm{t} \cdot$ compost $^{-h^{-1}}{ }^{-1}$, while in Meskan soil, the tallest plant height $(73.67 \mathrm{~cm})$ was achieved from the integrated application of $46 \mathrm{~kg} \cdot \mathrm{ha}^{-1} \cdot \mathrm{N}$ and $10 \mathrm{t} \cdot \mathrm{ha}^{-1}$ compost thoroughly followed by $92 \mathrm{~kg} \cdot \mathrm{ha}^{-1} \cdot \mathrm{N}$ and $10 \mathrm{t} \cdot \mathrm{ha}^{-1}$ compost. In both soil types, however, the unfertilized pot (control) gave the shortest plant height of maize. The addition of $138 \mathrm{~kg} \cdot \mathrm{ha}^{-1} \cdot \mathrm{N}$ and $10 \mathrm{t} \cdot \mathrm{ha}^{-1}$ compost and $46 \mathrm{~kg} \cdot \mathrm{ha}^{-1} \cdot \mathrm{N}$ and $10 \mathrm{t} \cdot \mathrm{ha}^{-1}$ compost increased maize plant height by 51.2 and $46.4 \%$ above the control in Hawassa Zuria and Meskan soils, respectively, which could be due to enhanced nutrient availability and uptake. This is consistent with the findings of Agegnehu et al. [29], who suggest that the combined use of biochar, compost, and inorganic fertilizer significantly improved maize plant height compared to the individual application. Shisanya et al. [47] reported similar observations in their experiment.

In both soil types, nitrogen levels by compost interaction significantly increased number of leaves per plant. The maximum number of leaves per plant was recorded from the incorporated use of $138 \mathrm{~kg} \cdot \mathrm{ha}^{-1} \cdot \mathrm{N}$ and $10 \mathrm{t} \cdot \mathrm{ha}^{-1}$ compost and $92 \mathrm{~kg} \cdot \mathrm{ha}^{-1} \cdot \mathrm{N}$ and $5 \mathrm{t} \cdot \mathrm{ha}^{-1}$ compost at Hawassa Zuria and Meskan soils, respectively (Table 3 ). However, the minimum number of leaves per plant was recorded from the unfertilized pot in both soil types (Table 3 ). This could be because nitrogen encouraged vegetative growth in maize. This result agrees with the findings of Adamu et al. [28] who stated that integrated use of compost and $\mathrm{N}$ fertilizer produced maximum leaf numbers per plant.

The results of this study showed that nitrogen and compost application at different rates had significant effect $(P<0.05)$ on the mean Normalized Difference Vegetative Index (NDVI). The maximum NDVI values 0.74 in Hawassa soil and 0.76 in Meskan soil were obtained from $138 \mathrm{~kg} \cdot \mathrm{ha}^{-1} \cdot \mathrm{N}+10 \mathrm{t} \cdot \mathrm{ha}^{-1}$ compost and $92 \mathrm{~kg} \cdot \mathrm{ha}^{-1} \cdot \mathrm{N}+10 \mathrm{t} \cdot \mathrm{ha}^{-1}$ compost, respectively (Table 3). However, the minimum NDVI value was recorded in the control treatment (Table 4). The addition of $138 \mathrm{~kg} \cdot \mathrm{ha}^{-1} \cdot \mathrm{N}+10 \mathrm{t} \cdot \mathrm{ha}^{-1}$ compost for Hawassa Zuria soil and $92 \mathrm{~kg} \cdot \mathrm{ha}^{-1} \cdot \mathrm{N}+10 \mathrm{t} \cdot \mathrm{ha}^{-1}$ compost for Meskan soil improved NDVI value by 29 and $25 \%$, as compared to the control treatment. In the current study, the integrated use of compost and inorganic $\mathrm{N}$ fertilizer increased NDVI values in general, and possibly nitrogen availability in the soil and uptake by plant enhanced due to compost amendment. Similar results reported by Alchanatis et al. [48] on maize leaf reflectance (near $550 \mathrm{~nm}$ wavelength) described that there is a strong association between NDVI and soil nitrogen contents. Based on the results, we make the following observation: the effect of inorganic $\mathrm{N}$ rates on NDVI was more than the compost, when inorganic $\mathrm{N}$ increased from zero to $138 \mathrm{~kg} \cdot \mathrm{ha}^{-1} \cdot \mathrm{N}$, the mean NDVI also consistently improved. However, the change owing to the application of compost rates was minimal and inconsistent (Table 4).

Analysis of variance revealed that stem girth was differed significantly among the fertilizer treatments in both soil types. The maximum stem girth of $1.61 \mathrm{~cm}$ was gained from the combined application of $138 \mathrm{~kg} \cdot \mathrm{ha}^{-1} \cdot \mathrm{N}+10 \mathrm{t} \cdot \mathrm{ha}^{-1}$ compost in Hawassa soil, which is statistically at par with $92 \mathrm{~kg} \cdot \mathrm{ha}^{-1} \cdot \mathrm{N}+10 \mathrm{t} \cdot \mathrm{ha}^{-1}$ compost and $92 \mathrm{~kg} \cdot \mathrm{ha}^{-1} \cdot \mathrm{N}+15 \mathrm{t} \cdot \mathrm{ha}^{-1}$, respectively, whereas in Meskan soil, the addition of $92 \mathrm{~kg} \cdot \mathrm{ha}^{-1} \cdot \mathrm{N}+10 \mathrm{t} \cdot \mathrm{ha}^{-1}$ compost produced wider stem girth, which is statistically at par with $92 \mathrm{~kg} \cdot \mathrm{ha}^{-1} \cdot \mathrm{N}+5 \mathrm{t}^{-\mathrm{ha}^{-1}} \mathrm{com}-$ post. In both soil types, however, the narrower stem girth was produced from the unfertilized pot (control). Adamu et al. [28] reported similar results in their experiments, which suggest that the integrated use of organic and inorganic nitrogen sources is prominent to plant growth, yield, and yield components.

The main and interaction effects of nitrogen and compost rates were significantly affected shoot and root dry weights (Table 5), but the magnitude of the effects was not usually analogous. The maximum shoot dry weight of maize in Hawassa soil was achieved from the integrated application of $138 \mathrm{~kg} \cdot \mathrm{ha}^{-1} \cdot \mathrm{N}+10 \mathrm{t} \cdot \mathrm{ha}^{-1}$ compost, which is statistically similar with $92 \mathrm{~kg} \cdot \mathrm{ha}^{-1} \cdot \mathrm{N}+10 \mathrm{t} \cdot \mathrm{ha}^{-1}$ compost, while unfertilized treatment gave the minimum value. The shoot dry biomass achieved from $138 \mathrm{~kg} \cdot \mathrm{ha}^{-1} \cdot \mathrm{N}+10 \mathrm{t} \cdot \mathrm{ha}^{-1}$ compost and $92 \mathrm{~kg} \cdot \mathrm{ha}^{-1} \cdot \mathrm{N}+10 \mathrm{t} \cdot \mathrm{ha}^{-1}$ compost treatments, respectively, was 1.85 and 1.79 times that of the unfertilized treatment (Table 5). In Meskan soil, addition of $92 \mathrm{~kg} \cdot \mathrm{ha}^{-1} \cdot \mathrm{N}+10 \mathrm{t} \cdot \mathrm{ha}^{-1}$ compost treatment produced superior shoot dry weight, which is statistically at par with $46 \mathrm{~kg} \cdot \mathrm{ha}^{-1} \cdot \mathrm{N}+10 \mathrm{t} \cdot \mathrm{ha}^{-1}$ compost. In this soil, the shoot dry biomass produced from the addition of $92 \mathrm{~kg} \cdot \mathrm{ha}^{-1} \cdot \mathrm{N}+10 \mathrm{t} \cdot \mathrm{ha}^{-1}$ compost and $46 \mathrm{~kg} \cdot \mathrm{ha}^{-1} \cdot \mathrm{N}+10 \mathrm{t} \cdot \mathrm{ha}^{-1}$ compost treatments, respectively, was 2.85 and 2.73 times that of the control (Table 5). The increase in shoot dry biomass from the integrated treatments could be ascribed to enhanced root development and nutrient uptake caused by compost application along with inorganic nitrogen. Various researchers reported similar results [29] who stated that the combined application of inorganic and organic nutrient sources produced significantly greater biomass as compared with sole application of inorganic or organic nutrient sources.

Similarly, application of different fertilizer treatments was significantly affected root dry biomass, where the maximum root dry weight values were obtained from $138 \mathrm{~kg} \cdot \mathrm{ha}^{-1} \cdot \mathrm{N}+15 \mathrm{t} \cdot \mathrm{ha}^{-1}$ compost and $92 \mathrm{~kg} \cdot \mathrm{ha}^{-1} \cdot \mathrm{N}+$ 10 th ha ${ }^{-1}$ compost treatments in Hawassa Zuria and Meskan soils, respectively (Table 5). In this trial, the greater shoot and root dry biomass obtained from the combined use of compost and inorganic nitrogen fertilizer might be due to the positive effect of compost in improving soil physical 
TABLE 3: Interaction effects of different inorganic nitrogen and compost rates on plant height and number of leaves per plant.

\begin{tabular}{|c|c|c|c|c|c|c|c|c|c|c|}
\hline \multirow{3}{*}{$\mathrm{N}\left(\mathrm{kg} \cdot \mathrm{ha}{ }^{1}\right)$} & \multicolumn{7}{|c|}{ Hawassa Zuria soil } & \multicolumn{3}{|c|}{ Meskan soil } \\
\hline & \multicolumn{10}{|c|}{ Compost rates $\left(\mathrm{t} \cdot \mathrm{ha}^{1}\right)$} \\
\hline & 0 & 5 & 10 & 15 & 20 & 0 & 5 & 10 & 15 & 20 \\
\hline \multicolumn{11}{|c|}{ Plant height $(\mathrm{cm})$} \\
\hline 0 & $50.8^{\mathrm{i}}$ & $59.5^{\mathrm{h}}$ & $67.7^{\text {cde }}$ & $68.3^{\text {cde }}$ & $69.5^{\mathrm{cd}}$ & $50.3^{\mathrm{i}}$ & $60.7^{\mathrm{efg}}$ & $61.5^{\mathrm{efg}}$ & $50.8^{\mathrm{i}}$ & $56.0^{\mathrm{h}}$ \\
\hline 46 & $68.3^{\text {cde }}$ & $61.4^{\mathrm{gh}}$ & $71.8^{\mathrm{bc}}$ & $64.0^{\text {efg }}$ & $69.5^{\mathrm{cd}}$ & $59.0^{\mathrm{gh}}$ & $62.8^{\mathrm{ef}}$ & $73.7^{\mathrm{a}}$ & $63.7^{\text {de }}$ & $68.7^{\mathrm{bc}}$ \\
\hline 92 & $67.5^{\text {cde }}$ & $70.5^{\mathrm{cd}}$ & $71.7^{\mathrm{bc}}$ & $75.2^{\mathrm{ab}}$ & $69.2^{\mathrm{cd}}$ & $68.3^{\mathrm{bc}}$ & $69.5^{\mathrm{bc}}$ & $71.8^{\mathrm{ab}}$ & $66.8^{\mathrm{cd}}$ & $68.0^{c}$ \\
\hline 138 & $67.7^{\text {cde }}$ & $76.7^{\mathrm{a}}$ & $76.8^{\mathrm{a}}$ & $66.7^{\mathrm{def}}$ & $63.0^{\text {fgh }}$ & $68.7^{\mathrm{bc}}$ & $59.0^{\mathrm{gf}}$ & $59.5^{\text {fgh }}$ & $58.1^{\mathrm{gh}}$ & $61.3^{\mathrm{efg}}$ \\
\hline LSD (0.05) & & & 4.39 & & & & & 3.59 & & \\
\hline CV (\%) & & & 3.92 & & & & & 3.45 & & \\
\hline \multicolumn{11}{|c|}{ Number of leaves per plant } \\
\hline 0 & $7.17^{\mathrm{c}}$ & $7.5^{\mathrm{c}}$ & $7.17^{\mathrm{c}}$ & $7.67^{\mathrm{bc}}$ & $7.67^{\mathrm{bc}}$ & $7.67^{\mathrm{d}}$ & $8.33^{\mathrm{abc}}$ & $8.00^{\mathrm{bcd}}$ & $8.17^{\mathrm{abcd}}$ & $8.33^{\mathrm{abc}}$ \\
\hline 46 & $7.83^{\mathrm{abc}}$ & $7.50^{\mathrm{c}}$ & $7.50^{\mathrm{c}}$ & $7.17^{\mathcal{C}}$ & $7.50^{\mathrm{c}}$ & $8.50^{\mathrm{ab}}$ & $7.83^{\mathrm{cd}}$ & $8.33^{\mathrm{abc}}$ & $8.33^{\mathrm{abc}}$ & $7.83^{\mathrm{cd}}$ \\
\hline 92 & $7.33^{\mathrm{c}}$ & $7.83^{\mathrm{abc}}$ & $7.67^{\mathrm{bc}}$ & $8.00^{\mathrm{abc}}$ & $7.83^{\mathrm{abc}}$ & $8.50^{\mathrm{ab}}$ & $8.67^{\mathrm{a}}$ & $8.33^{\mathrm{abc}}$ & $8.33^{\mathrm{abc}}$ & $8.17^{\mathrm{abcd}}$ \\
\hline 138 & $7.83^{\mathrm{abc}}$ & $8.67^{\mathrm{ab}}$ & $8.83^{\mathrm{a}}$ & $8.17^{\mathrm{abc}}$ & $7.67^{\mathrm{bc}}$ & $8.50^{\mathrm{ab}}$ & $8.50^{\mathrm{ab}}$ & $8.33^{\mathrm{abc}}$ & $7.67^{\mathrm{d}}$ & $8.17^{\mathrm{abcd}}$ \\
\hline LSD (0.05) & & & 1.03 & & & & & 0.59 & & \\
\hline $\mathrm{CV}(\%)$ & & & 8.10 & & & & & 4.39 & & \\
\hline
\end{tabular}

Within the columns, means followed by the same letters are not significantly different at $P>0.05$ (LSD).

TABle 4: Interaction effects of different inorganic nitrogen and compost rates on Normalized Difference Vegetative Index and stem girth.

\begin{tabular}{|c|c|c|c|c|c|c|c|c|c|c|}
\hline \multirow{3}{*}{$\mathrm{N}\left(\mathrm{kg} \cdot \mathrm{ha}^{1}\right)$} & \multicolumn{7}{|c|}{ Hawassa Zuria soil } & \multicolumn{3}{|c|}{ Meskan soil } \\
\hline & \multicolumn{10}{|c|}{ Compost rates $\left(\mathrm{t} \cdot \mathrm{ha}^{\mathrm{l}}\right)$} \\
\hline & 0 & 5 & 10 & 15 & 20 & 0 & 5 & 10 & 15 & 20 \\
\hline \multicolumn{11}{|c|}{ Normalized Difference Vegetative Index } \\
\hline 0 & $0.57^{\mathrm{i}}$ & $0.63^{\text {fgh }}$ & $0.62^{\mathrm{gh}}$ & $0.63^{\text {efg }}$ & $0.66^{\text {cde }}$ & $0.59^{\mathrm{i}}$ & $0.67^{\mathrm{ef}}$ & $0.66^{\text {efg }}$ & $0.63^{\mathrm{h}}$ & $0.64^{\mathrm{gh}}$ \\
\hline 46 & $0.68^{\mathrm{bc}}$ & $0.68^{\mathrm{bc}}$ & $0.60^{\mathrm{h}}$ & $0.66^{\text {cde }}$ & $0.60^{\mathrm{h}}$ & $0.65^{\text {fgh }}$ & $0.67^{\mathrm{ef}}$ & $0.67^{\mathrm{ef}}$ & $0.71^{\mathrm{bc}}$ & $0.67^{\mathrm{ef}}$ \\
\hline 92 & $0.65^{\text {cdef }}$ & $0.65^{\text {defg }}$ & $0.70^{\mathrm{b}}$ & $0.68^{\mathrm{bc}}$ & $0.64^{\text {defg }}$ & $0.72^{\mathrm{bc}}$ & $0.7^{\mathrm{bc1}}$ & $0.76^{\mathrm{a}}$ & $0.74^{\mathrm{a}}$ & $0.68^{\mathrm{de}}$ \\
\hline 138 & $0.67^{\mathrm{cd}}$ & $0.71^{\mathrm{b}}$ & $0.74^{\mathrm{a}}$ & $0.67^{\mathrm{cd}}$ & $0.64^{\text {efg }}$ & $0.68^{\mathrm{de}}$ & $0.70^{\mathrm{cd}}$ & $0.72^{\mathrm{abc}}$ & $0.70^{\mathrm{cd}}$ & $0.71^{\mathrm{c}}$ \\
\hline LSD (0.05) & & & 0.03 & & & & & 0.02 & & \\
\hline CV $(\%)$ & & & 2.64 & & & & & 2.07 & & \\
\hline \multicolumn{11}{|c|}{ Stem girth diameter $(\mathrm{cm})$} \\
\hline 0 & $1.04^{\mathrm{f}}$ & $1.2 \mathrm{def}$ & $1.13^{\mathrm{ef}}$ & $1.28^{\mathrm{cde}}$ & $1.44^{\mathrm{abc}}$ & $1.11^{\mathrm{i}}$ & $1.21^{\text {fghi }}$ & $1.30^{\text {defg }}$ & $1.21^{\text {fghi }}$ & $1.14^{\mathrm{hi}}$ \\
\hline 46 & $1.42^{\mathrm{abc}}$ & $1.50^{\mathrm{ab}}$ & $1.27^{\text {cde }}$ & $1.21^{\mathrm{def}}$ & $1.36^{\mathrm{bcd}}$ & $1.3^{\text {defg }}$ & $1.37^{\text {cde }}$ & $1.38^{\text {cde }}$ & $1.37^{\mathrm{cde}}$ & $1.08^{\mathrm{i}}$ \\
\hline 92 & $1.29^{\text {cde }}$ & $1.45^{\mathrm{abc}}$ & $1.40^{\mathrm{bc}}$ & $1.45^{\mathrm{abc}}$ & $1.3^{\text {bcde }}$ & $1.3^{\text {efgh }}$ & $1.57^{\mathrm{ab}}$ & $1.62^{\mathrm{a}}$ & $1.17^{\text {ghi }}$ & $1.17^{\text {ghi }}$ \\
\hline 138 & $1.31^{\mathrm{cde}}$ & $1.42^{\mathrm{abc}}$ & $1.61^{\mathrm{a}}$ & $1.44^{\mathrm{abc}}$ & $1.41^{\mathrm{bc}}$ & $1.3^{\text {efgh }}$ & $1.37^{\text {cde }}$ & $1.32^{\mathrm{def}}$ & $1.51^{\mathrm{abc}}$ & $1.44^{\mathrm{bcd}}$ \\
\hline LSD (0.05) & & & 0.19 & & & & & 0.15 & & \\
\hline $\mathrm{CV}(\%)$ & & & 8.50 & & & & & 6.89 & & \\
\hline
\end{tabular}

Within the columns, means followed by the same letters are not significantly different at $P>0.05$ according to the LSD test.

properties, slowing mineralization, and nutrient release, and thus increasing the efficiency of inorganic fertilizer. Previous studies also suggested that the combined use of compost and inorganic nitrogen fertilizer could be a better alternative option for soil fertility improvement and subsequently yield and yield components $[26,29]$.

\subsection{Effects of Different Nitrogen Levels and Compost Rates on} Maize Seedling Nitrogen Concentration and Uptake. In both soil types, the main and interaction effects of nitrogen fertilizer and compost (Figures 3(a) and 4(a)) significantly influenced nitrogen concentration through maize vegetation. In Hawassa Zuria soil, plant $\mathrm{N}$ concentration progressively improved with the increase in nitrogen and compost rates. A consistent increasing trend observed in plant $\mathrm{N}$ concentration with $\mathrm{N}$ rates increased from 0 to $138 \mathrm{~kg} \cdot \mathrm{ha}^{-1}$ and compost rates from zero to $20 \mathrm{t} \cdot \mathrm{ha}^{-1}$.
However, these phenomena did not appear in Meskan soil, possibly due to initial soil TN dissimilarity being between the two experimental soils (Table 1). In Meskan soil, plant $\mathrm{N}$ concentration significantly improved with the increase in mineral nitrogen from 0 to $46 \mathrm{~kg} \cdot \mathrm{N} \cdot \mathrm{ha}^{-1}$ and compost rates from zero to $15 \mathrm{t} \cdot \mathrm{ha}^{-1}$ compost (Figure $4(\mathrm{a})$ ). The high plant nitrogen concentration implies that higher nitrogen was kept in the soil solution and available to the plants. In Hawassa Zuria soil, the combined addition of $138 \mathrm{~kg} \cdot \mathrm{ha}^{-1} \cdot \mathrm{N}+10 \mathrm{t} \cdot \mathrm{ha}^{-1}$ compost caused the maximum mean plant $\mathrm{N}$ concentration of $3.36 \%$, which is statistically similar with $138 \mathrm{~kg} \cdot \mathrm{ha}^{-1} \cdot \mathrm{N}+5 \mathrm{t} \cdot \mathrm{ha}^{-1}$ compost treatment, whereas in Meskan soil, the combined addition of $46 \mathrm{~kg} \cdot \mathrm{ha}^{-1} \cdot \mathrm{N}+20 \mathrm{t} \cdot \mathrm{ha}^{-1}$ compost produced the maximum mean plant $\mathrm{N}$ concentration of $2.47 \%$, thoroughly followed by $46 \mathrm{~kg} \cdot \mathrm{ha}^{-1} \cdot \mathrm{N}+15 \mathrm{t} \cdot \mathrm{ha}^{-1}$ compost and $92 \mathrm{~kg} \cdot \mathrm{ha}^{-1} \cdot \mathrm{N}+15 \mathrm{t} \cdot \mathrm{ha}^{-1}$ compost (Figure 4(a)). In contrast, the lowest plant nitrogen concentrations of 0.73 and $0.67 \%$ were recorded from the 
TABLE 5: Effects of different nitrogen levels and compost rates on the shoot dry weights, root dry weights, and relative shoot dry matter.

\begin{tabular}{|c|c|c|c|c|c|c|}
\hline \multirow{2}{*}{ Treatments } & \multicolumn{3}{|c|}{ Hawassa Zuria soil } & \multicolumn{3}{|c|}{ Meskan soil } \\
\hline & RDW (g/pot) & $\operatorname{ASDW}(\mathrm{g} / \mathrm{pot})$ & RSDM (100\%) & RDW (g/pot) & ASDW (g/pot) & RSDM (100\%) \\
\hline Control & $6.70^{\text {cdefgh }}$ & $14.65^{j}$ & 100.00 & $5.90^{\mathrm{j}}$ & $10.88^{\mathrm{i}}$ & 100 \\
\hline $\mathrm{N}_{0}+\mathrm{Com}_{5}$ & $7.64^{\mathrm{abcd}}$ & $15.94^{\mathrm{ij}}$ & 108.78 & $7.16^{\mathrm{fghi}}$ & $16.76^{\mathrm{h}}$ & 154.04 \\
\hline $\mathrm{N}_{0}+\operatorname{Com}_{10}$ & $5.99^{\text {fghi }}$ & $15.02^{\mathrm{j}}$ & 102.50 & $6.69^{\mathrm{hij}}$ & $17.38^{\mathrm{gh}}$ & 159.77 \\
\hline $\mathrm{N}_{0}+\operatorname{Com}_{15}$ & $7.55^{\text {abcde }}$ & $16.54^{\text {hij }}$ & 112.92 & $7.21^{\text {fghi }}$ & $19.94^{\mathrm{fg}}$ & 183.24 \\
\hline $\mathrm{N}_{0}+\mathrm{Com}_{20}$ & $6.79^{\text {cdef }}$ & $18.06^{\text {fghig }}$ & 123.30 & $6.05^{j}$ & $22.61^{\mathrm{ef}}$ & 207.81 \\
\hline $\mathrm{N}_{46}+\mathrm{Com}_{0}$ & $5.71^{\mathrm{ghi}}$ & $18.25^{\text {efghig }}$ & 124.57 & $7.32^{\text {fgh }}$ & $25.06^{\text {cde }}$ & 230.30 \\
\hline $\mathrm{N}_{46}+\mathrm{Com}_{5}$ & $6.37^{\mathrm{defgh}}$ & $19.77^{\text {efghig }}$ & 134.97 & $9.25^{\mathrm{ab}}$ & $26.10^{\mathrm{bcd}}$ & 239.92 \\
\hline $\mathrm{N}_{46}+\operatorname{Com}_{10}$ & $6.44^{\text {defgh }}$ & $18.21^{\text {efghig }}$ & 124.32 & $6.73^{\text {hijk }}$ & $29.74^{\mathrm{a}}$ & 273.32 \\
\hline $\mathrm{N}_{46}+\mathrm{Com}_{15}$ & $5.62^{\mathrm{ghi}}$ & $17.46^{\text {ghij }}$ & 119.20 & $8.28^{\text {cde }}$ & $28.75^{\mathrm{ab}}$ & 264.25 \\
\hline $\mathrm{N}_{46}+\operatorname{Com}_{20}$ & $5.20^{\mathrm{i}}$ & $22.35^{\text {bcdef }}$ & 152.56 & $6.31^{\mathrm{ij}}$ & $24.14^{\mathrm{de}}$ & 221.90 \\
\hline $\mathrm{N}_{92}+\operatorname{Com}_{0}$ & $7.06^{\text {bcdef }}$ & $21.09^{\text {cdefg }}$ & 143.98 & $8.74^{\mathrm{bcd}}$ & $28.83^{\mathrm{ab}}$ & 264.98 \\
\hline $\mathrm{N}_{92}+\mathrm{Com}_{5}$ & $7.15^{\text {bcdef }}$ & $22.65^{\text {bcde }}$ & 154.61 & $7.87^{\mathrm{def}}$ & $30.61^{\mathrm{a}}$ & 281.34 \\
\hline $\mathrm{N}_{92}+\operatorname{Com}_{10}$ & $6.68^{\text {cdefgh }}$ & $26.29^{\mathrm{ab}}$ & 179.48 & $9.78^{\mathrm{a}}$ & $30.95^{\mathrm{a}}$ & 284.47 \\
\hline $\mathrm{N}_{92}+\operatorname{Com}_{15}$ & $7.79^{\mathrm{abc}}$ & $24.21^{\mathrm{abcd}}$ & 165.28 & $6.69^{\text {hij }}$ & $28.08^{\mathrm{abc}}$ & 258.12 \\
\hline $\mathrm{N}_{92}+\operatorname{Com}_{20}$ & $6.09^{\text {fghi }}$ & $20.76^{\text {cdefgh }}$ & 141.73 & $9.02^{\mathrm{abc}}$ & $24.14^{\mathrm{de}}$ & 221.88 \\
\hline $\mathrm{N}_{138}+\operatorname{Com}_{0}$ & $7.03^{\text {bcde }}$ & $24.25^{\mathrm{abc}}$ & 165.51 & $8.82^{\mathrm{bc}}$ & $22.69^{\mathrm{ef}}$ & 208.52 \\
\hline $\mathrm{N}_{138}+\mathrm{Com}_{5}$ & $8.02^{\mathrm{ab}}$ & $24.46^{\mathrm{abc}}$ & 166.99 & $9.36^{\mathrm{ab}}$ & $28.52^{\mathrm{ab}}$ & 262.13 \\
\hline $\mathrm{N}_{138}+\operatorname{Com}_{10}$ & $8.08^{\mathrm{ab}}$ & $27.15^{\mathrm{a}}$ & 185.32 & $8.78^{\mathrm{bcd}}$ & $24.18^{\text {de }}$ & 222.22 \\
\hline $\mathrm{N}_{138}+\operatorname{Com}_{15}$ & $8.38^{\mathrm{a}}$ & $25.81^{\mathrm{ab}}$ & 176.18 & $7.70^{\mathrm{ef}}$ & $23.65^{\mathrm{de}}$ & 217.40 \\
\hline $\mathrm{N}_{138}+\operatorname{Com}_{20}$ & $5.53^{\mathrm{hi}}$ & $22.64^{\text {bcde }}$ & 154.54 & $7.62^{\text {efg }}$ & $22.59^{\mathrm{ef}}$ & 207.63 \\
\hline LSD (0.05) & 1.21 & 4.44 & - & 0.92 & 3.07 & - \\
\hline CV (\%) & 10.79 & 12.93 & - & 7.15 & 7.65 & - \\
\hline
\end{tabular}

$\mathrm{RDW}=$ root dry weight; ASDW = absolute shoot dry weight; RSDM = relative shoot dry matter. Within the columns, the means followed by the same letters are not significantly different at $P<0.05$ according to the LSD test.

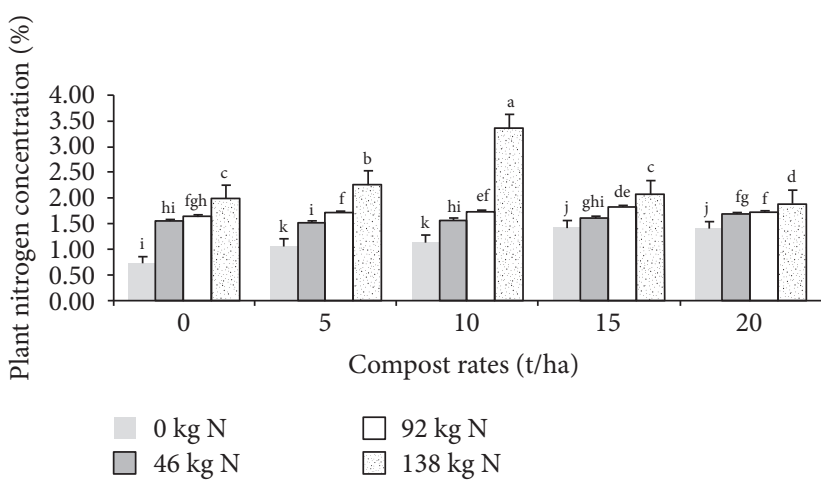

(a)

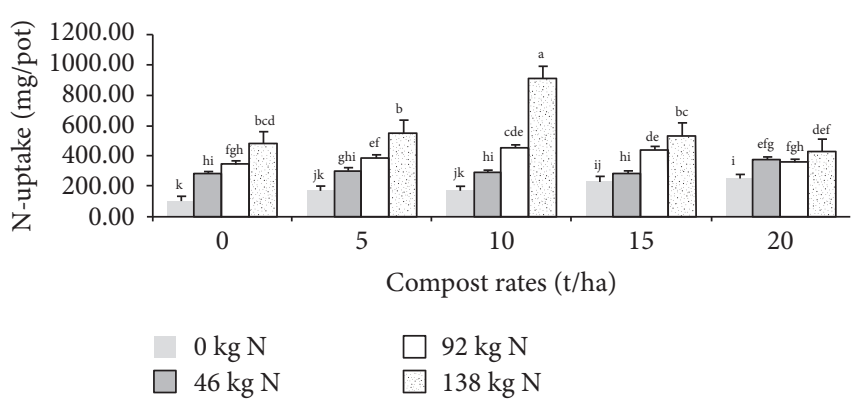

(b)

Figure 3: Effect of nitrogen and compost rates on nitrogen concentration (a) and N-uptake (b) of maize growth in Hawassa Zuria soil. Different letters indicate significance between treatments at $P \leq 0.05$ according to the LSD test.

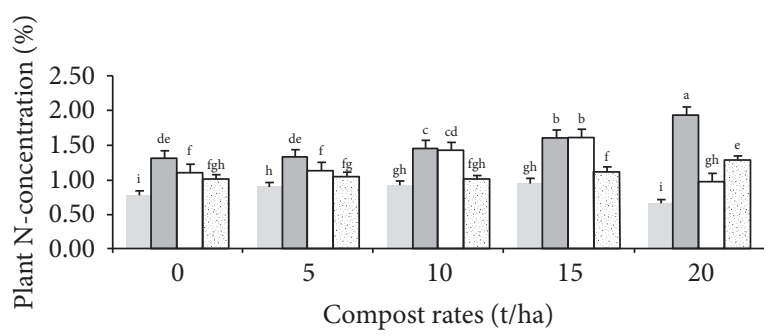

(a)

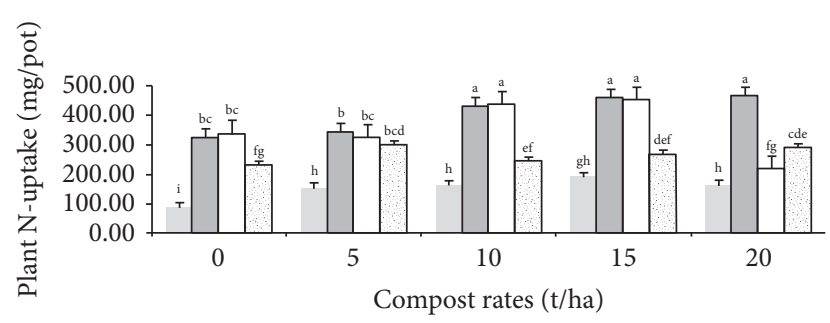

(b)

FIgURE 4: Effect of nitrogen and compost rates on nitrogen concentration (a) and N-uptake (b) of maize growth in Meskan soil. Different letters indicate significance between treatments at $P \leq 0.05$ according to the LSD test. 
TABLE 6: Eigenvalue, percentage, cumulative variances, and eigenvectors of first four principal components (PC1-4) for nine characters in twenty treatments.

\begin{tabular}{|c|c|c|c|c|c|c|c|c|}
\hline \multirow{2}{*}{ Parameters } & \multicolumn{4}{|c|}{ Hawassa Zuria soil } & \multicolumn{4}{|c|}{ Meskan soil } \\
\hline & $\mathrm{PC} 1$ & PC2 & PC3 & PC4 & PC1 & PC2 & PC3 & PC4 \\
\hline Eigenvalue & 6.14 & 1.08 & 0.52 & 0.50 & 4.68 & 1.51 & 1.07 & 0.64 \\
\hline$\%$ variance & 68 & 12 & 6 & 6 & 52 & 17 & 12 & 07 \\
\hline Cumulative & 68 & 80 & 86 & 92 & 52 & 69 & 81 & 88 \\
\hline Characters & \multicolumn{8}{|c|}{ Eigenvectors } \\
\hline PHT & 0.306 & 0.096 & 0.016 & 0.850 & 0.364 & -0.144 & 0.219 & 0.170 \\
\hline LNPP & 0.366 & 0.181 & -0.171 & 0.009 & 0.207 & 0.370 & 0.673 & 0.258 \\
\hline NDVI & 0.352 & 0.168 & 0.194 & -0.254 & 0.404 & 0.134 & -0.088 & 0.132 \\
\hline SG & 0.333 & -0.004 & -0.429 & -0.416 & 0.281 & 0.329 & -0.195 & -0.757 \\
\hline SDW & 0.359 & -0.327 & 0.078 & -0.079 & 0.427 & 0.027 & 0.183 & -0.065 \\
\hline RDW & 0.158 & 0.860 & 0.145 & -0.091 & 0.281 & 0.472 & -0.223 & 0.045 \\
\hline Plant N-content & 0.376 & -0.120 & -0.254 & 0.106 & 0.304 & -0.581 & -0.041 & -0.097 \\
\hline Soil N-content & 0.312 & -0.207 & 0.790 & -0.118 & 0.273 & 0.054 & -0.602 & 0.528 \\
\hline Plant N-uptake & 0.381 & -0.163 & -0.181 & 0.009 & 0.393 & -0.390 & 0.083 & -0.141 \\
\hline
\end{tabular}

control treatment in Hawassa Zuria and sole $20 \mathrm{t} \cdot$ compost $\mathrm{ha}^{-1}$ in Meskan soil, which is statistically like the unfertilized pot, respectively. Hence, plant $\mathrm{N}$ concentration increased by $\sim 360 \%$ and $247 \%$ due to the addition of $138 \mathrm{~kg} \cdot \mathrm{ha}^{-1} \cdot \mathrm{N}+10 \mathrm{t} \cdot \mathrm{ha}^{-1}$ compost and $46 \mathrm{~kg} \cdot \mathrm{ha}^{-1} \cdot \mathrm{N}+20 \mathrm{t} \cdot \mathrm{ha}^{-1}$ compost as compared to the control in Hawassa Zuria and Meskan soils, respectively. Agegnehu et al. [29] showed that organic amendments such as compost and biochar with inorganic fertilizer considerably increased plant total $\mathrm{N}$ and $\mathrm{NO}_{3}-\mathrm{N}$ concentration relative to the control.

Similarly, nitrogen uptake by maize plants was significantly affected by the main and interaction effects of inorganic nitrogen and compost rates in both soil types (Figures 3(b) and 4(b)). In Hawassa soil, the highest mean $\mathrm{N}$-uptake of $912.2 \mathrm{mg} \cdot \operatorname{pot}^{-1}$ was attained from the addition of $138 \mathrm{~kg} \cdot \mathrm{ha}^{-1} \cdot \mathrm{N}+10 \mathrm{t} \cdot \mathrm{ha}^{-1}$ compost, with the $\mathrm{N}$-uptake increment of $88.3 \%$ as compared to the control (unfertilized) treatment, while in Meskan soil, the integrated use of $46 \mathrm{~kg} \cdot \mathrm{ha}^{-1} \cdot \mathrm{N}+20 \mathrm{t} \cdot \mathrm{ha}^{-1}$ compost produced a maximum mean $\mathrm{N}$-uptake of $465.9 \mathrm{mg} \cdot \mathrm{pot}^{-1}$, with the $\mathrm{N}$-uptake increment of $81.8 \%$ as compared to the unfertilized treatment. However, the lowest nitrogen uptake value was observed in control and sole $20 \mathrm{t} \cdot \mathrm{ha}^{-1}$ compost in Hawassa Zuria and Meskan soils, respectively. In both soil types, coupled use of mineral $\mathrm{N}$ with compost significantly improved nitrogen uptake, but it has different responses to the applied fertilizer treatments. This is consistent with the findings of Abedi et al. [49], who suggest that the integrated use of organic and inorganic inputs considerably improved nutrient and water uptake, solely either organic or inorganic amendment since organic inputs potentially enhanced soil physical properties and root development. Vanlauwe et al. [50] reported that the combined use of compost and inorganic fertilizer resulted in the highest $\mathrm{AE}$ of $\mathrm{N}$.

Analysis of the data depicted that the first two principal components (PC1 and PC2) accounted 80 and $69 \%$ of the total disparity of the treatments in Hawassa Zuria and Meskan soils, respectively, of which PC1 was contributed $68 \%$ for Hawassa Zuria and 52\% for Meskan site (Table 6). In this study, except for root dry weight for Hawassa Zuria soil and leaf number per plant for Meskan soil, in the first eigenvector, other parameters independently contributed comparable effects to the treatment's total variation. It ranged from 0.306 to 0.381 and 0.273 to 0.427 in Hawassa Zuria and Meskan soils, respectively, suggesting that first principal component provided a realistic summary of the data and described most of the deviation in the entire dataset. The maximum values (0.381 and 0.427$)$ were recorded from the plant $\mathrm{N}$-uptake and shoot dry weight characters in Hawassa Zuria and Meskan soils, respectively, indicating that these variables influenced the grouping more than those with lower values do.

The variables such as stem girth, shoot dry weight, plant, and soil N-content had positive loadings on second eigenvector, but plant height, leaf number per plant, NDVI, and root dry biomass showed negative loadings in Hawassa soil (Table 6), whereas in Meskan soil, negative loadings showed on the variables plant height, nitrogen concentration, and nitrogen uptake, but the remaining characters have positive loading (Table 6). Therefore, mostly the cumulative effects of several characters should dictate the variation among treatments into different clusters than an individual variance. Similarly, Agegnehu et al. [29] compared the conventional business as a usual fertilizer treatment with different soil fertility treatments containing organic and inorganic sources, using PCA to determine optimum soil amendments.

In both soil types, significant associations were detected among plant growth parameters, and plant and soil nitrogen contents $(P \leq 0.05)$. In Hawassa Zuria soil, the Normalized Difference Vegetative Index (NDVI) was positively significantly correlated with maize plant height, leaf number per plant, stem girth, shoot weight, plant nitrogen concentration, and soil nitrogen content $(r=0.60,0.74,0.73,0.66,0.76$, and 0.69 ), respectively (Table 7 ), whereas in Meskan soil, plant height, stem girth, shoot and root dry weights, plant nitrogen concentration, and soil total nitrogen content were positively significantly associated with NDVI of the leaves $(r=0.61,0.55,0.74,0.58,0.45,0.59$, and 0.63$)$, respectively. The red NDVI $r=$ value for shoot dry weight is similar with the values for maize yield $(r=0.7-0.8)$ [51] and $(r=0.65)$ Inman et al. [52]. 
TABLE 7: Correlation coefficients among soil and plant parameters of maize grown on the two soils from Hawassa Zuria and Meskan districts of Southern Ethiopia. Upper right side for Meskan soil and lower left side for Hawassa Zuria soil.

\begin{tabular}{lccccccccc}
\hline Characters & PHT & LNPP & NDVI & SG & SDW & RDW & NC (\%) & Soil TN (\%) & N-uptake \\
\hline PHT & 1 & $0.38^{\text {ns }}$ & $0.61^{* *}$ & $0.32^{\text {ns }}$ & $0.69^{* *}$ & $0.34^{\text {ns }}$ & $0.56^{* *}$ & $0.34^{\text {ns }}$ & $0.69^{* *}$ \\
LNPP & $0.67^{* *}$ & 1 & $0.42^{\text {ns }}$ & $0.22^{\text {ns }}$ & $0.54^{*}$ & $0.33^{\text {ns }}$ & $-0.04^{\text {ns }}$ & $0.01^{\text {ns }}$ & $0.21^{\text {ns }}$ \\
NDVI & $0.60^{*}$ & $0.74^{* *}$ & 1 & $0.55^{*}$ & $0.74^{* *}$ & $0.58^{* *}$ & $0.45^{*}$ & $0.59^{* *}$ & $0.63^{* *}$ \\
SG & $0.53^{*}$ & $0.73^{* *}$ & $0.73^{* *}$ & 1 & $0.55^{*}$ & $0.53^{*}$ & $0.15^{\text {ns }}$ & $0.31^{\text {ns }}$ & $0.35^{\text {ns }}$ \\
SDW & $0.61^{*}$ & $0.73^{* *}$ & $0.69^{* *}$ & $0.74^{* *}$ & 1 & $0.53^{*}$ & $0.55^{*}$ & $0.43^{\text {ns }}$ & $0.82^{* * *}$ \\
RDW & $0.33^{\text {ns }}$ & $0.51^{*}$ & $0.47^{*}$ & $0.29^{\text {ns }}$ & $0.09^{\text {ns }}$ & 1 & $0.04^{\text {ns }}$ & $0.45^{*}$ & $0.25^{\text {ns }}$ \\
NC (\%) & $0.69^{* *}$ & $0.85^{* * *}$ & $0.76^{* * *}$ & $0.73^{* *}$ & $0.82^{* * *}$ & $0.24^{\text {ns }}$ & 1 & $0.32^{\text {ns }}$ & $0.92^{* * *}$ \\
Soil TN (\%) & $0.52^{*}$ & $0.61^{*}$ & $0.69^{* *}$ & $0.51^{*}$ & $0.78^{* * *}$ & $0.18^{\text {ns }}$ & $0.63^{* *}$ & 1 \\
N-uptake & $0.69^{* *}$ & $0.85^{* * *}$ & $0.76^{* * *}$ & $0.73^{* *}$ & $0.82^{* * *}$ & $0.24^{\text {ns }}$ & $0.99^{* * *}$ & $0.63^{*}$ & $0.36^{\text {ns }}$ \\
\hline
\end{tabular}

PHT = plant height; LNPP = leaf number per plant; NDVI = Normalized Difference Vegetative Index; SDW = shoot dry weight; SG = stem girth; RDW = root dry weight; $\mathrm{NC}=$ nitrogen concentration; Soil $\mathrm{TN}=$ soil total nitrogen; $\mathrm{N}$-uptake $=$ nitrogen uptake. ${ }^{*} P<0.05,{ }^{* *} P<0.01$, and ${ }^{* * *} P<0.001$; ns: not significant.

Pearson correlation coefficient of shoot dry weight under different fertilizer treatments was positively significantly correlated with maize plant height, leaf number per plant, mean NDVI, stem girth, plant nitrogen concentration, soil nitrogen content, and nitrogen uptake $(r=0.61,0.73,0.69$, $0.74,0.82,0.78$, and 0.89), respectively, in Hawassa Zuria soil. Similarly, in Meskan soil, shoot dry weight was positively significantly associated with maize plant height, leaf number per plant, mean NDVI, root dry weight, plant nitrogen content, and nitrogen uptake $(r=0.69,0.54,0.74$, $0.53,0.55$, and 0.82 , respectively) (Table 7 ). The observations are consistent with the findings of Agegnehu and Amede [20] indicated that shoot and root dry weight were significantly correlated with plant growth parameters, chlorophyll content, plant nitrogen concentration, and nitrogen uptake.

\section{Conclusion}

Our results evidently demonstrated that the combined application of compost and inorganic $\mathrm{N}$ fertilizer significantly improved soil organic carbon and total nitrogen contents. Moreover, the integrated use of compost and mineral $\mathrm{N}$ fertilizer significantly enhanced plant growth and nitrogen uptake, compared to the unfertilized or separate addition of compost and inorganic $\mathrm{N}$ fertilizer. In Hawassa Zuria soil, the treatment $138 \mathrm{~kg} \cdot \mathrm{ha}^{-1} \cdot \mathrm{N}+10 \mathrm{t} \cdot \mathrm{ha}^{-1}$ compost was superior to other treatments but statistically similar to $92 \mathrm{~kg} \cdot \mathrm{ha}^{-1} \cdot \mathrm{N}+10 \mathrm{t} \cdot \mathrm{ha}^{-1}$ compost. Similarly, plant nitrogen concentration and uptake were significantly improved; the highest was achieved with the application $138 \mathrm{~kg} \cdot \mathrm{ha}^{-1} \cdot \mathrm{N}+10 \mathrm{t} \cdot \mathrm{ha}^{-1}$. In Meskan soil, the addition of $92 \mathrm{~kg} \cdot \mathrm{ha}^{-1} \cdot \mathrm{N}+10 \mathrm{t} \cdot \mathrm{ha}^{-1}$ compost treatment produced superior shoot dry biomass and nitrogen uptake, which is statistically at par with $46 \mathrm{~kg} \cdot \mathrm{ha}^{-1} \cdot \mathrm{N}+10 \mathrm{t} \cdot \mathrm{ha}^{-1}$ compost. From the results of the current study, it could be concluded that the combined application of $92 \mathrm{~kg} \cdot \mathrm{ha}^{-1} \cdot \mathrm{N}+10 \mathrm{t} \cdot \mathrm{ha}^{-1}$ compost and $46 \mathrm{~kg} \cdot \mathrm{ha}^{-1} \cdot \mathrm{N}+10 \mathrm{t} \cdot \mathrm{ha}^{-1}$ was the best treatments for Hawassa Zuria and Meskan soils, respectively, which improved shoot dry matter by 179.5 and $284.5 \%$, compared to the unfertilized pot, respectively. However, additional research is required under field situations to ascertain the advantages and effects of these amendments on soil fertility, crop yield, and economic returns to farmers.

\section{Data Availability}

The data used to support the findings of this study are included in the results part of the manuscript.

\section{Conflicts of Interest}

The authors declare that they have no conflicts of interest.

\section{Authors' Contributions}

Ashenafi Nigussie conducted over all activities such as proposal writing, literature review, data collection and statistical analysis, and manuscript write-up. Wassie Haile designed and supervised the research and data interpretation and editing. Getachew Agegnehu critically reviewed and helped in the result interpretation and cosupervised research. Alemayehu Kiflu helped in soil laboratory analysis and editing and cosupervised research.

\section{Acknowledgments}

The authors express their genuine acknowledgment to the Wondo Genet Agricultural Research Center and Natural Resource Management Research Process of WGARC for all the necessary facilities they provide for the accomplishment of this study. The authors are also grateful to Mr. Bishery Abdo and his colleagues for assistance in the analysis of soil samples at the Analytical Laboratory of Hawassa University College of Agriculture.

\section{References}

[1] L. Greiner, A. Keller, A. Grêt-Regamey, and A. Papritz, "Soil function assessment: review of methods for quantifying the contributions of soils to ecosystem services," Land Use Policy, vol. 69, pp. 224-237, 2017.

[2] M. K. Abbasi and A. Khizar, "Microbial biomass carbon and nitrogen transformations in a loam soil amended with organic-inorganic $\mathrm{N}$ sources and their effect on growth and N-uptake in maize," Ecological Engineering, vol. 39, pp. 123132, 2012.

[3] M. G. Farouque and H. Tekeya, "Farmersâ€ use of integrated soil fertility and nutrient management practices for sustainable crop production: a field-level study in Bangladesh," 
American Journal of Agricultural and Biological Sciences, vol. 3, no. 4, pp. 716-723, 2008.

[4] FAO (Food and Agriculture Organization), Lecture Notes on the Major Soils of the World, FAO, Rome, Italy, 2001.

[5] CSA (Central Statistical Agency), Annual Agricultural Sample Survey Reports from 2015/16, CSA (Central Statistical Agency), Addis Ababa, Ethiopia, 2016.

[6] D. Spielman, D. Kelemework, and D. Alemu, Policies to Promote Smallholder Intensification in Ethiopia. The Search for Appropriate Public and Private Roles, IFPRI, Addis Ababa, Ethiopia, 2009.

[7] W. Negassa, T. Abera, D. K. Friesen, A. Deressa, and B. Dhinsa, "Evaluation compost for maize production under farmers' conditions," in Proceedings of the Seventh Eastern and Southern African Regional Maize Conference, D. K. Friesen and A. F. E. Palmer, Eds., CIMMYT, Nairobi, Kenya, February 2004.

[8] A. M. Gelaw, B. R. Singh, and R. Lal, "Soil organic carbon and total nitrogen stocks under different land uses in a semi-arid watershed in Tigray, Northern Ethiopia," Agriculture, Ecosystems \& Environment, vol. 188, pp. 256-263, 2014.

[9] G. Kumar, M. Singh, R. Kumar et al., "Yield and quality of fodder turnip as affected by nitrogen application and weed management during winter lean periods," Indian Journal of Animal Nutrition, vol. 32, pp. 57-62, 2015.

[10] R. Lal, "Restoring soil quality to mitigate soil degradation," Sustainability, vol. 7, no. 5, pp. 5875-5895, 2015.

[11] S. Mohan, M. Singh, and R. Kumar, "Effect of nitrogen, phosphorus and zinc fertilization on yield and quality of khariffodder-a review," Agricultural Reviews, vol. 36, no. 3, pp. 218-226, 2015.

[12] T. S. Agba and H. S. Long, "Nitrogen effects on maize foliage and grain yield," Nigerian Agricultural Journal, vol. 3, pp. 74-80, 2005.

[13] J. O. S. Kogbe and J. A. Adediran, "Influence of nitrogen, phosphorus and potassium application on the yield of maize in the savanna zone of Nigeria," African Journal of Biotechnology, vol. 2, no. 10, pp. 345-349, 2003.

[14] J. B. O. Ogola, T. R. Wheeler, and P. M. Harris, "Effects of nitrogen and irrigation on water use of maize crops," Field Crops Research, vol. 78, no. 2-3, pp. 105-117, 2002.

[15] B. R. Baral and P. Adhikari, "Use of optical sensor for inseason nitrogen management and grain yield prediction in maize," Journal of Maize Research and Development, vol. 1, no. 1, pp. 64-70, 2015.

[16] J. Blumenthal, D. Baltensperger, K. G. Cassman, S. Mason, and A. Pavlista, "Importance and effect of nitrogen on crop quality and health," Nitrogen in the Environment: Sources, Problems and Management, Elsevier, Amsterdam, Netherlands, 2nd edition, 2008.

[17] Y. Sheng, Y. Zhan, and L. Zhu, "Reduced carbon sequestration potential of biochar in acidic soil," Science of The Total Environment, vol. 572, pp. 129-137, 2016.

[18] Z. Feng and L. Zhu, "Impact of biochar on soil $\mathrm{N}_{2} \mathrm{O}$ emissions under different biochar-carbon/fertilizer-nitrogen ratios at a constant moisture condition on a silt loam soil," Science of The Total Environment, vol. 584-585, pp. 776-782, 2017.

[19] P. Hepperly, D. Lotter, C. Z. Ulsh, R. Seidel, and C. Reider, "Compost, manure and synthetic fertilizer influences crop yields, soil properties, nitrate leaching and crop nutrient content," Compost Science \& Utilization, vol. 17, no. 2, pp. 117-126, 2009.

[20] G. Agegnehu and T. Amede, "Integrated soil fertility and plant nutrient management in tropical agro-ecosystems: a review," Pedosphere, vol. 27, no. 4, pp. 662-680, 2017.
[21] J. Zhao, T. Ni, J. Li et al., "Effects of organic-inorganic compound fertilizer with reduced chemical fertilizer application on crop yields, soil biological activity and bacterial community structure in a rice-wheat cropping system," Applied Soil Ecology, vol. 99, pp. 1-12, 2016.

[22] M. Fereidooni, F. Raiesi, and S. Fallah, "Ecological restoration of soil respiration, microbial biomass and enzyme activities through broiler litter application in a calcareous soil cropped with silage maize," Ecological Engineering, vol. 58, pp. 266277, 2013.

[23] M. S. Salim and H. Mahmoodul, Annual Technical Report of Project Improvement of Soil Productivity through Biological Mean, Pakistan Agricultural Research Council, Islamabad, Pakistan, 2001.

[24] A. W. Kramer, T. A. Doane, W. R. Horwath, and C. V. Kessel, "Combining fertilizer and organic inputs to synchronize $\mathrm{N}$ supply in alternative cropping systems in California," Agriculture, Ecosystems \& Environment, vol. 91, no. 1-3, pp. 233-243, 2002.

[25] A. A. Amoah, M. Senge, S. Miyagawa, and K. Itou, "Effects of soil fertility management on growth, yield, and water-use efficiency of maize (Zea mays L.) and selected soil properties," Communications in Soil Science and Plant Analysis, vol. 43, no. 6, pp. 924-935, 2012.

[26] E. Solomon and D. Jafer, "Yield response of maize to integrated soil fertility management on acidic nitosol of Southwestern Ethiopia," Journal of Agronomy, vol. 14, no. 3, pp. 152-157, 2015.

[27] B. L. Abdulrahman, M. U. Dawaki, and I. Muhammad, "Effect of organic and inorganic nitrogen sources on soil properties and maize seedling nitrogen uptake," Applied Tropical Agriculture, vol. 21, no. 3, pp. 186-191, 2016.

[28] U. Adamu, J. Mrema, and J. Msaky, "Growth response of maize (Zea mays L.) to different rates of nitrogen, phosphorus and farm yard manure in Morogoro Urban district, Tanzania," American Journal of Experimental Agriculture, vol. 9, no. 2, pp. 1-8, 2015.

[29] G. Agegnehu, M. I. Bird, P. N. Nelson, and A. M. Bass, "The ameliorating effects of biochar and compost on soil quality and plant growth on a Ferralsol," Soil Research, vol. 53, no. 1, pp. 1-12, 2015.

[30] S. Bokhtiar and K. Sakurai, "Effects of organic manure and chemical fertilizer on soil fertility and productivity of plant and ratoon crops of sugarcane," Archives of Agronomy and Soil Science, vol. 51, no. 3, pp. 325-334, 2005.

[31] M. J. Kiani, M. K. Abbasi, and N. Rahim, "Use of organic manure with mineral $\mathrm{N}$ fertilizer increases wheat yield at Rawalakot Azad Jammu and Kashmir," Archives of Agronomy and Soil Science, vol. 51, no. 3, pp. 299-309, 2005.

[32] S. Sertsu and T. Bekele, "Procedures for soil and plant analysis," EIAR, Addis Ababa, Ethiopia, Technical paper, 2000.

[33] A. Walkley and I. A. Black, "An examination of the degtjareff method for determining soil organic matter, and a proposed modification of the chromic acid titration method," Soil Science, vol. 37, no. 1, pp. 29-38, 1934.

[34] L. P. Van Reeuwijk, Procedures for Soil Analysis, International Soil Reference and Information Centre Wageningen (ISRIC), Wageningen, The Netherlands, 3rd edition, 1992.

[35] S. R. Olsen, C. V. Cole, F. S. Watanabe, and L. A. Dean, "Estimation of available phosphorus in soils by extraction with sodium carbonate," USDA Circular, vol. 939, pp. 1-19, 1954.

[36] Y. Wu, W. Liu, X. Li et al., "Low-nitrogen stress tolerance and nitrogen agronomic efficiency among maize inbreds: 
comparison of multiple indices and evaluation of genetic variation," Euphytica, vol. 180, no. 2, pp. 281-290, 2011.

[37] SAS Institute, PROC User's Manual, Version 9.3, SAS Institute Inc., Cary, NC, USA, 2014.

[38] P. Hazelton and B. Murphy, Interpreting Soil Test Results: What Do All Numbers Mean? CSIRO Publishing, Melbourne, Australia, 2007.

[39] J. J. Benton, Agronomic Handbook: Management of Crops, Soils, and Their Fertility, CRC Press, Boca Raton, FL, USA, 2003.

[40] J. R. Landon, Booker Tropical Soil Manual: A Handbook for Soil Survey and Agricultural Land Evaluation in the Tropics and Subtropics, p. 474, Longman Scientific and Technical Publishers, Essex, UK, 1991.

[41] J. L. Havlin, J. D. Beaton, S. L. Tisdale, and W. L. Nelson, Soil Fertility and Fertilizers, Prentice-Hall, New Jersey, NJ, USA, 6th edition, 1999.

[42] J. Dhillon, M. R. Del Corso, B. Figueiredo, E. Nambi, and W. Raun, "Soil organic carbon, total nitrogen, and soil $\mathrm{pH}$, in a long-term continuous winter wheat (Triticum Aestivum L.) experiment," Communications in Soil Science and Plant Analysis, vol. 49, no. 7, pp. 803-813, 2018.

[43] M. Hafidi, S. Amir, A Meddich et al., "Impact of applying composted bio solids on wheat growth and yield parameters on a calcimagnesic soil in a semi-arid region," African Journal of Biotechnology, vol. 11, pp. 9805-9815, 2012.

[44] P. L. Preusch, P. R. Adler, L. J. Sikora, and T. J. Tworkoski, "Nitrogen and phosphorus availability in composted and uncomposted poultry litter," Journal of Environmental Quality, vol. 31, no. 6, pp. 2051-2057, 2002.

[45] D. Yan, D. Wang, and L. Yang, "Long-term effect of chemical fertilizer, straw, and manure on labile organic matter fractions in a paddy soil," Biology and Fertility of Soils, vol. 44, no. 1, pp. 93-101, 2007.

[46] G. Sarwar, H. Schmeisky, N. Hussain, S. Muhammad, M. Ibrahim, and E. Safdar, "Improvement of soil physical and chemical improvement with compost application in ricewheat cropping system," Pakistan Journal of Botany, vol. 40, pp. 275-282, 2008.

[47] C. A. Shisanya, M. W. Mucheru, D. N. Mugendi, and J. B. Kung'u, "Effect of organic and inorganic nutrient sources on soil mineral nitrogen and maize yields in central highlands of Kenya," Soil and Tillage Research, vol. 103, no. 2, pp. 239-246, 2009.

[48] V. Alchanatis, Z. Schmilovitch, and M. Meron, "In-field assessment of single leaf nitrogen status by spectral reflectance measurements," Precision Agriculture, vol. 6, no. 1, pp. 25-39, 2005.

[49] T. Abedi, A. Alemzadeh, and S. A. KazemeIni, "Effect of organic and inorganic fertilizers on grain yield and protein banding pattern of wheat," Australian Journal of Crop Science, vol. 4, no. 6, pp. 384-389, 2010.

[50] B. Vanlauwe, J. Kihara, P. Chivenge, P. Pypers, R. Coe, and J. Six, "Agronomic use efficiency of $\mathrm{N}$ fertilizer in maize-based systems in sub-Saharan Africa within the context of integrated soil fertility management," Plant and Soil, vol. 339, no. 1-2, pp. 35-50, 2011.

[51] R. K. Teal, B. Tubana, K. Girma et al., "In-season prediction of corn grain yield potential using normalized difference vegetation index," Agronomy Journal, vol. 98, no. 6, pp. 1488-1494, 2006.

[52] D. Inman, R. Khosla, and T. Mayfield, "On-the-go active remote sensing for efficient crop nitrogen management," Sensor Review, vol. 25, no. 3, pp. 209-214, 2005. 